\title{
Characterization and conservation of indigenous livestock genetic resources for wealth creation in tropical Africa: A review
}

\author{
A. Ahmadu ${ }^{1}$, H. I. Kubkomawa ${ }^{2}$, N. S. Abubakar' ${ }^{2}$ T. Sini' ${ }^{2}$, J. H. Chama², R. H. Gapsiso ${ }^{2}$ and M. \\ S. Adamu²
}

\begin{abstract}
1Department of Animal Science, Ahmadu Bello University (ABU) Zaria, Kaduna State, Nigeria.
2Department of animal health and production Technology, the Federal Polytechnic, P. M. B. 35, Mubi, Adamawa State, Nigeria.

*Corresponding author. Email: ahmaduafiniki@gmail.com. Tel: +234763445757.

Copyright (@) 2016 Ahmadu et al. This article remains permanently open access under the terms of the Creative Commons Attribution License 4.0, which permits unrestricted use, distribution, and reproduction in any medium, provided the original work is properly cited.
\end{abstract}

Received 23rd July, 2016; Accepted 23rd August, 2016

\begin{abstract}
The objective of the study was to review the methods of characterization and conservation of indigenous livestock genetic resources for wealth creation in tropical Africa. Animal genetic resources have been contributing to food and agriculture for more than 12, 000 years, providing the human population with a wide range of food products, along with fibre, manure for crops, droppings for fuel and draught power. In addition, animal genetic resources frequently reduce farmers' risk exposure, generate employment and contribute to rural development. It is estimated that, directly or indirectly, domestic animals contribute 30 to 40 percent of the total value of food and Agriculture production in Nigeria. In the course of the development of diverse human societies, livestock became a very important cultural element and is essential in maintaining many traditional lifestyles. Farmers and breeders have been using animal genetic diversity effectively to develop breeds and varieties that were suitable for local environmental conditions and provided for different human needs and wants. The domestication process and breeding under different environments has resulted in over 6,000 identified breeds developed within about 40 animal species. The total diversity of animal genetic resources available to farmers makes it possible for humans to survive in a wide range of production environments, from hot-humid tropics to arid deserts and cold, severe mountainous regions. Genetic diversity also supported livestock adaptation to many limiting environmental factors, such as diseases, parasites, wide variations in the availability and quality of feed and water, and extreme temperatures. It is therefore, concluded that, animal genetic resources should be preserved and conserved and not be allowed to erode away. Local breeds that are hardy and withstand harsh climates should not be let go to extinction because of their role to wealth creation in both rural and urban communities in Nigeria and tropical Africa as a whole.
\end{abstract}

Keywords: Animal, conservation, genetic resources, tropical Africa, wealth.

\section{INTRODUCTION}

Farmers around the world use over 4,500 breeds or strains of domestic livestock of some 40 species. But nearly one third (approximately six breeds per month become extinct) of the world's livestock breeds are currently at risk of disappearing and further erosion in animal diversity will result in the loss of options for use in increasing long-term productivity (Hammond, 2002; FAO,
2013; Alemayehu, 3013). There is already less genetic variation in farm animals than in crop plant species (ILCA, 1992; Wollny, 2001; FAO, 2007). Further erosion invites disaster as the environmental and economic risks facing small farmers and poor communities are certain to increase in coming years (ILCA, 1992; Wollny, 2001; FAO, 2007). 
With declining animal genetic resources, possible unidentified genes within non-specialized, indigenous breeds of livestock in tropical developing countries are at risk from being lost forever. These unidentified genes could be vital in future breeding programs (Rege, 1992). Concern over this loss of biodiversity in recent years resulted in the signing of the Convention of Biological Diversity by 159 countries and signatories are now obligated to develop national plans for the conservation and use of biodiversity (Renée and Aloyzas, 2003). This is often difficult for developing countries that may have no real idea of the number and types of each breed of livestock. However, a new FAO initiative for domestic animal diversity, is providing support (through its Global Strategy for the Management of Farm) to enable these countries to obtain genetic information through surveying and spot censors of different breeds. Africa, for instance, has been divided into three regions with each country within a region collaborating through an existing regional organization (Renée and Aloyzas, 2003). Training in evaluating genetic resources will also be available. The International Livestock Research Institute's (ILRI) is also involved in sustaining the diversity of important domesticated animal genetic resources in developing countries by encouraging and supporting the availability of this germplasm for research and animal improvement programs. Genetic fingerprinting (molecular characterization) is also being used by ILRI to determine how closely 150 of Africa's cattle breeds are related to each other. The ultimate goal is to classify populations into distinct genetic groups so as to facilitate rational conservation and use of these Animal genetic resources in the future.

To help improve productivity in African livestock, ILRI scientists are involved in identifying and conserving tropical livestock breeds that may carry genes controlling resistance to diseases. In particular, the N'Dama breed of cattle is currently being assessed for its tolerance to trypanosomiasis: ILRI scientists are looking for sequences of DNA that 'mark' the genes controlling resistance to trypanosomiasis so that, in future, these resistant genes might be transferred to other breeds that are more productive than N'Dama cattle (e.g. Boran cattle in East Africa and European dairy cattle in West Africa) (Blench, 1999). The effect of internal parasites in the tropics is one of the most important constraints to small ruminant production. A sustainable and low-cost solution could be provided by breeding for parasite resistance: in Ethiopia, two indigenous breeds of sheep (Horro and Menz) are currently being assessed for their resistance to gastro-intestinal parasites and their ability to survive on low quality diet. Similar studies on Red Maasai and Dorper sheep from the coastal region of Kenya have already revealed that Red Maasai demonstrate a better resistance to endoparasites (Blench, 1999; FAO, 2013a).

At ICARDA (International Centre for Agricultural Research in the Dry Areas), Shami or Damascus goats from Syria are being studied for their genetic potential in relation to milk production and varying nutritional feeds. Shami goats generally have a good high yield of milk, even under the harsh climatic conditions of the region, and a high twinning and kidding rate throughout the year which makes them popular with local farmers (FAO, 2013a). However, more sheep are generally found in the region so by comparing the results of the Shami goat trials with similar trials conducted on Awassi sheep at Tel Hadya and published data on dairy cows, ICARDA can assess the true potential of these goats (Hammond, 2002; FAO, 2013a).

Indigenous breeds are also being studied and conserved at different centers across Taiwan by the Taiwan Livestock Research Institute. Amongst the species of livestock which are being conserved is the endangered Taiwan Native Goat. This particular conservation program includes the establishment of a small population of goats as well as storage of frozen semen and embryos. Chinese Geese are also being conserved whilst hybrids of Chinese geese and foreign breeds are being tested for better growth performance and meat quality (Wollny, 2001; FAO, 2007).

In many conservation programs, farmers have an important role to play in the assessment of genetic resources as they know the characteristics of their breed with regards to disease resistance, climate adaptation and productivity. Farmers often select their most productive livestock for controlled breeding and may even castrate inferior males to help maintain the breed characteristics within the herd or flock. However, farmers need to be supported in their work as the increasing pressures of food demands and decreasing availability of land can result in the abandonment of traditional breeds in the search for greater productivity. Farmers need financial, scientific and technical support to enable them to conserve and use traditional varieties while experimenting with and developing new varieties. One way of doing this is by promoting an appreciating indigenous varieties and breeds as well as developing markets for them to increase farm income while ensuring conservation. At the same time, farmers' indigenous livestock knowledge should be documented for future breeding programs. The objective of the study was to review the methods of characterization and conservation of indigenous livestock genetic resources for wealth creation in tropical Africa.

\section{CHARACTERIZATION OF LIVESTOCK GENETIC RESOURCES IN NIGERIA}

Characterization of animal genetic encompasses all activities associated with the identification, quantitative and qualitative description, documentation of breed populations and the natural habitats and production systems to which they are or are not adapted (Rege, 
1992; Yunusa et al., 2013). The sustainable management, utilization and conservation of a particular population of domestic animals require its characterization (FAO, 2007). Characterization, in genetic terms, refers to the detection of variation as a result of differences in either DNA sequences or specific genes or modifying factors (Adekoya et al., 2013; De Vicente et al., 2005). Genetic characterization includes the collection and analysis of DNA from each breed of interest, in order to evaluate genetic variability at molecular level and determine relationships among breeds. Guidelines on molecular characterization are available to assist countries in this activity (FAO, 2011). National-level characterization comprises the identification of the country's animal genetic and the surveying of these resources (Rege, 1992). The process also includes the systematic documentation of the information gathered so as to allow easy access. The aim is to obtain better knowledge of animal genetic, of their present and potential future uses for food and Agriculture in defined environments, and their current state as distinct breed populations (FAO, 1984; Rege, 1992). Characterization activities should contribute to objective and reliable prediction of animal performance in defined environments, so as to allow a comparison of potential performance within the various major production systems found in a country or region. It is, therefore, more than the mere accumulation of existing reports (FAO 2001; Assan 2014).

\section{ROLE OF LIVESTOCK IN THE NATIONAL ECONOMY AND HOUSEHOLDS}

Table 1 presents the common breeds of livestock found in Nigeria and are very important in boosting the economy of majority of Nigerian populace.

\section{Cattle}

Cattle are highly valued livestock in Nigeria and elsewhere in tropical Africa, where it contributes to the local economy and food security. Cattle are kept mostly for beef, milk, manure and hide. They also serve other socio cultural functions such as payment of bride price, transportation of goods and people, prestige and symbol of economic status. When cattle production is combined with crop production enterprise, the land becomes more effectively utilized. Cattle can be used to pull ploughs on the farm for tilling and cultivation of land (i.e. Animal traction). Cattle dung can be used in the production of methane gas. They can be raised comfortably on lands that are unsuitable for crops (Blench, 1999; NAAS, 2001).

\section{Sheep}

In sub-saharan Africa, sheep provide almost $30 \%$ of the meat consumed and around $16 \%$ of the milk produced (Gatenby, 1995; Rotimi et al., 2013). Sheep contributes about $50 \%$ of the total domestically produced meat in Nigeria. Apart from the production of meat and milk, wool, skin and manure are also good by-products of sheep. Nigeria possesses about 22.1 million sheep which thrive well in a wide variety of environments in the tropics and sub-tropics. It requires less capital as they can be completely maintained on pastures, browse, and agricultural waste products. A flock of sheep can provide families with food each day in the form of milk but only in limited parts of the world are sheep milked for dairy food (Gatenby, 1995; Rotimi et al., 2013). Countries in Southern and Eastern Europe and some developing countries such as Syria and Turkey consume fresh sheep milk in reasonable quantities. Sheep milk is an excellent raw material for the milk processing industry especially in cheese production. Genotype, animal's feed, health, weather conditions, the number of lambs, milking technique, the botanical composition of the pastures and other factors have a great influence on sheep milk. The Mediterranean countries are the biggest producers of sheep milk. They participate with approximately $47 \%$ in the overall world production of sheep milk. Sheep milk yields 18 to 25 percent cheese, whereas goat and cow milk only yield 9 to 10 percent (Gatenby, 1995; Rotimi et al., 2013). While sheep usually produce less milk than goats and much less than cows, sheep milk sells for a significantly higher price per pound, almost four times the price of cow milk. Large consumption of sheep milk is thought to lead to longevity. Bulgarian shepherds are noted for their exceptionally long lives, presumably from a diet of the produce of their sheep. Because of its high calcium content, sheep milk is also very good for the prevention of osteoporosis and for those people already suffering from it. Sheep milk is the most nutritious milk on sale in the world today. The only other milk that can be compared with it would be that of the camel and the water buffalo.

\section{Goats}

Goats are the most numerous livestock that makes a major contribution to the agrarian economy in Nigeria and tropical Africa (Tizhe et al., 2015). Nigeria has over 24.5 million goats representing almost $4 \%$ of world population (Tizhe et al., 2015). They contribute about 17\% $(65,000$ tones) of the local meat supply in Nigeria. Goats are used for the provision of additional income from the sale of meat, milk, wool and manure in most African families including Nigeria (Tizhe et al., 2015).

\section{Swine}

Over the years, the need for more animal protein to sustain an exponentially increasing population has led to an obvious increase in livestock production through the 
Table 1. Breeds of livestock found in Nigeria.

\begin{tabular}{|c|c|c|c|c|c|c|c|c|}
\hline \multirow{2}{*}{ No. } & \multicolumn{8}{|c|}{ Breed } \\
\hline & Cattle & Sheep & Goat & Poultry & Rabbit & Swine & Camel & Donkey \\
\hline 1 & Bunaji & Balami & $\begin{array}{l}\text { Sahel or Desert } \\
\text { goat }\end{array}$ & Chicken & Chinchilla & Duroc & Bakinbiri & Auraki \\
\hline 2. & N'dama & Uda & Sokoto Red Goat & Turkey & Himalayan & Landrace & $\mathrm{Ja}$ & Duni \\
\hline 3 & $\begin{array}{l}\text { Sokoto } \\
\text { Gudali }\end{array}$ & Yankasa & $\begin{array}{l}\text { West African } \\
\text { Dwarf goat }\end{array}$ & Ostrich & $\begin{array}{l}\text { Giant } \\
\text { Flemish }\end{array}$ & Large white & Mabari & Idabari \\
\hline 4 & $\begin{array}{l}\text { Adamawa } \\
\text { Gudali }\end{array}$ & $\begin{array}{l}\text { West African } \\
\text { Dwarf }\end{array}$ & Borno White & $\begin{array}{l}\text { Guinea } \\
\text { fowl }\end{array}$ & $\operatorname{Rex}$ & Hampshire & Taquwa & Fari \\
\hline 5 & Keteku & & & Duck & $\begin{array}{l}\text { New } \\
\text { Zealand } \\
\text { White }\end{array}$ & Pietrain & Kurri & Bakinjaki \\
\hline 6 & Kuri & & & Quail & California & & Kala & Auroko \\
\hline 7 & Rahaji & & & Goose & Angora & & Bule & Ehokusu \\
\hline 8 & Awazak & & & Pigeon & Dutch & & & Goho \\
\hline 9 & Wadara & & & Canary & & & & Gwambaza \\
\hline 10 & Ambala & & & $\begin{array}{l}\text { Pea } \\
\text { cock }\end{array}$ & & & & Janqora \\
\hline 11 & $\begin{array}{l}\text { West } \\
\text { African } \\
\text { Dwarf } \\
\text { Shorthorn }\end{array}$ & & & Parrot & & & & \\
\hline
\end{tabular}

Sources: (RIM, 1992; Akinola, 2015; Blench et al., 1992; Ibitoye and Hassan 2016; Abdussamad et al., 2011).

establishment of large, industrial sized piggery. These piggery farms apart from producing pork, oil, bristles, hooves, casing and intestine for surgical use are also produced. Dung from pigs is also used for the production of biogas and solid cooking biofuel (Iregbu et al., 2014; Akinola, 2015).

\section{Rabbits}

Rabbits are raised for their white meat which is loved by all, and can be raised either on a small-scale by individual households, or on larger commercial scales (Mailafia et al., 2010; Oluwatusin, 2014). Furthermore, there are few cultural or religions or beliefs which do not allow the eating of rabbit meat. Rabbits can be fed on a great variety of locally available foods, some green leaves and kitchen vegetable scraps at almost no cost. This means that a rabbitry can expand quickly and take advantage of a plentiful feed supply. Even the backyard rabbit keeper can provide a constant supply of meat for his family. Rabbit's skins, wool, leather can be used for several purposes (mats, rugs and clothes). The manure is a valuable organic fertilizer for use in a vegetable garden. Rabbits are also used as laboratory animals for research purposes and testing of drugs (Mailafia et al., 2010; Oluwatusin, 2014).

\section{Poultry}

Poultry outnumbers all other forms of livestock in Nigeria
(Blench, 1999), and, not surprisingly, is found throughout the country, wherever there is human settlement. Although pigeons, ducks, guinea fowl and some turkeys are also widely kept, chickens are by far the most common. The economic services rendered by poultry specie include the provision of poultry meat, egg, feathers. The poultry is used to know when the day is approaching by cock crowing. Its litter is used as source of organic manure (Blench, 1999; NAAS, 2001).

\section{Camels}

There are three types of camels, which are one-hump camels, two-hump camels, and camel cigarettes. Dromedary is the name for one-hump camels. This type of camel is common to Africa and the Middle East. It was exported all over the world and is now relatively common in Australia and North America, where it has been used sporadically over the years as a pack animal. Dromedary camels are much more common than two hump camels and much less common than camel cigarettes (Mammeri et al., 2014; Bernard, 2015).

Bactrian Camels are much less common than dromedary (one-hump). Bactrian camels are native to the Gobi Desert in Mongolia. Aside from the obvious difference of the number of humps, Bactrian Camels differ in a few other key ways. For example, the Bactrian camel grows a thick coat of hair each winter. That coat of hair falls off every spring. This is to deal with the extreme variation of temperature in the Gobi desert where summer 
highs often top 100 degrees Fahrenheit, and winter months can see significant amounts of snow. In general, Bactrian camels are much more mild-mannered than their hot-tempered dromedary kin. (The Dromedary camel has a uniform length of hair year round.) Due to lower numbers, and the higher regard in the eyes of breeders, Bactrian camels command much higher prices than Dromedary camels (Mammeri et al., 2014; Bernard, 2015).

Their ability to survive without water for several days makes them ideal for work in arid environments and degraded regions of the semi-arid zone (Wilson, 1986). However, camel meat and milk are not popular in Northern Nigeria but are consumed in other African countries (Blench, 1992; Abdussamad et al., 2011).

\section{Donkey}

Donkeys are not conventional sources of meat, and their uses for packing and traction do not fit within the stereotyped perspectives of livestock development agencies. Nonetheless, they are essential to the subsistence strategies of many communities in semi-arid regions, relieving families of repetitive and energyconsuming tasks. The early history of the donkey in Africa is difficult to reconstruct because of the sparse archaeological data. The wild relatives of the donkey have been hunted to virtual extinction making it difficult to collect the genetic data necessary to establish its ancestry in detail and incidentally, has depleted the potential gene pool that might be used to revitalize domestic donkey breeds (Blench, 1999; Ibitoye and Hassan, 2016). They are cheap to maintain with good body condition on a poor diet and resist disease. In Nigeria, the Kano donkey (jakin Kano), is proverbial and used to be the principal pack animal for the import and export of materials in Hausa land (Blench 1999; Abdussamad et al., 2011).

\section{MANAGEMENT OF LIVESTOCK GENETIC RESOUR- CES TO PREVENT THEM FROM BEEN ERODED}

Developing the strategic framework for the management of farm animal genetic resources includes:

\section{Establishing national conservation policies}

African countries have the responsibility of conserving their animal genetic resources. Such policies should serve to ensure the maintenance of animal genetic resources with direct values for human use, including production, ecological, social and cultural values, as well as option values for future use and adaptation (Drucker, 2001). Production and functional traits, and national capacity, should be taken into consideration in setting conservation priorities. The erosion of animal genetic resources has complex drivers and cannot be halted by one simple solution. In Africa, a combination of in situ and ex situ conservation measures is necessary. In situ and ex situ conservation methods for animal genetic resources are still under development. Particularly in the area of ex situ conservation, there is a considerable need for standardized methods and technologies (Hagmann, 2003; FAO, 2007).

In situ conservation measures allow for the maintenance and adaptive management of animal genetic resources in productive landscapes. They facilitate continued co-evolution in diverse environments, and avoid stagnation of the genetic stock. In situ conservation measures are best based on agroecosystem approaches and, ideally, should be established through economically profitable and socially beneficial sustainable use. However, in some instances this can only be achieved after initial investments in creating markets and in product development. In cases where this is not possible, support for the in situ conservation of animal genetic resources may be necessary (FAO, 2007).

Ex situ conservation measures provide backup insurance against losses of animal genetic resources in the field, either through erosion or as a result of emergencies. Ex situ measures are complementary to in situ measures, and should be linked, where appropriate. Ex situ collections can also play an active role in strategic breeding programs.

\section{Developing and implementing regional and global long-term conservation strategies}

There are considerable numbers of regional and international transboundary breeds. Collaboration for in situ conservation is desirable for regional transboundary breeds and for livestock populations held by pastoralist communities that cross national boundaries. To ensure the highest efficiency and cost-saving in implementing ex situ conservation measures, regional and global strategies and facilities may be preferred over the duplication of national efforts, providing that modalities are developed for sharing facilities among countries and that conservation policies remain part of national sovereignty, and that such measures are consistent with existing international agreements. In the medium and long term, and taking into account likely environmental and socio-economic change, as well as disasters and emergencies, it is likely that international interdependence with regard to animal genetic resources will increase (FAO, 2007; FAO, 2013b).

\section{Establishing or strengthening national educational and research facilities}

Research and education needs strengthening in all areas of management of animal genetic resources. Establishing, 
strengthening and maintaining research and education institutions is key to building national capacities to plan and implement priority activities for the characterization, inventory and monitoring of risks and trends; sustainable use and development; and conservation of animal genetic resources (FAO, 2007; FAO, 2013b).

\section{Establishing or strengthening international information sharing, research and education}

Established international research and education institutions, including in the CGIAR system, provide major public goods through research and capacity-building, as well as through information systems, of relevance to animal genetic resources. Food and Agriculture Organization through its technical programs, also contributes actively to this work (FAO, 2007; FAO, 2013b).

\section{Establishing Regional Focal Points and strengthen international networks}

The management of transboundary breeds and populations, as well as specific regional socio-economic, cultural and environmental characteristics, provides a rationale for coordination and collaboration at the regional level. Investment in joint activities (such as gene banking) may often be more efficient and cost effective than the multiplication of overlapping national activities (FAO, 2007).

\section{Raising regional and international awareness of the roles and values of animal genetic resources}

There is a need to raise awareness including within environmental and broader agricultural and development institutions and forums, and among other stakeholders, such as donors and civil society of the important roles and values of animal genetic resources, their specific characteristics and the consequent needs for sustainable use, development and conservation (FAO, 2013b).

\section{Reviewing and developing national policies and legal frameworks for animal genetic resources}

A range of policies and legal instruments have direct or indirect effects on the use, development and conservation of animal genetic resources. These instruments often pursue different objectives, such as economic development, environmental protection, animal health, food safety, consumer protection, intellectual property rights, genetic resources conservation, and access to and equitable sharing of benefits arising from the use of animal genetic resources. Enhanced coherence between these instruments and policies is needed, without compromising their objectives, or the key objective of food security, and taking into account the distinctive features of animal genetic resources that need distinctive solutions. Means for access and benefitsharing need to be taken into account (FAO, 2007; FAO, 2013).

Strengthening efforts to mobilize resources for conservation, sustenance and development of animal genetic resources

Global efforts to mobilize resources for the conservation, sustainable use and development of animal genetic resources, both nationally and internationally, fall far short of the needs. The success of the Global Plan of Action for Animal Genetic Resources will depend on mobilizing financial resources, and on providing a coherent framework for exchange of information, access to and transfer of technology and capacity-building (FAO, 2013b).

\section{ESTABLISHMENT OF A GENE BANK FOR STORING GERMPLASM FROM ANIMALS}

Maintaining genetic material from animals belonging to the original population will allow genetic variability to be recovered if the population drifts from its original base, and will facilitate reconstitution of the breed if a catastrophic event (e.g. disease, fire or natural disaster) wipes out a significant portion of the live population (FAO, 2013b).

\section{Organize production and use of male animals}

Ideally, it will be possible to use the ex situ population as a resource in the active management and improvement of the in situ population, for example, by making superior young males from the herd available for use in the general population. Additional advice on ex situ in vivo management of animal genetic resources with very small populations can be found in guidelines produced by the European Livestock Breeds Ark and Rescue Net (FAO 2007; ELBARN, 2009).

\section{Conservation of Livestock Genetic Resources}

In the African context, conservation is "The rational use and protection of existing local genotypes from genetic introgression" (Hall, 1992; FAO 2013b). From a European standpoint, breed conservation is seen as the protection of rare breeds (up to 1,500 breeding females) (Rege, 1992).Conservation of animal genetic resources refers to 
all human activities including strategies, plans, policies and actions undertaken to ensure that the diversity of animal genetic resources being maintained to contribute to food and agricultural production and productivity, or to maintain other values of these resources (ecological, cultural) now and in the future (Wollny, 2001).

\section{METHODS OF CONSERVATION OF LIVESTOCK GENETIC RESOURCES}

A number of methods have been used for conservation of livestock genetic resources. These include in situ conservation of the breeds/populations, cryopreservation of semen, ova, embryos, skin, blood, DNA fragments, etc. These methods are relevant when the breed is rare or near extinction (NAAS, 2001).

\section{In situ conservation}

Refers to conservation of livestock through continued use by livestock keepers in the production system in which the livestock evolved or are now normally found and bred (FAO, 2007; FAO, 2013b).

\section{Ex situ in vivo conservation}

Refers to conservation through maintenance of live animal populations not kept under normal management conditions (e.g. zoological parks and in some cases governmental farms) and/or outside of the area in which they evolved or are now normally found. There is often no clear boundary between in situ and ex situ in vivo conservation and care must be taken to describe the conservation objectives and the nature of the conservation in each case (FAO, 2007; FAO, 2013b).

\section{Ex situ in vitro conservation}

Refers to conservation external to the living animal in an artificial environment, under cryogenic conditions including, inter alia, the cryoconservation of embryos, semen, oocytes, somatic cells or tissues having the potential to reconstitute live animals (including animals for gene introgression and synthetic breeds) at a later date (FAO, 2007; FAO, 2013b).

\section{IMPORTANCE OF CONSERVATION OF LIVESTOCK GENETIC RESOURCES}

Domestic animals supply some $30 \%$ of total human requirements for food and agriculture by providing final and intermediate outputs (FAO, 1999). These vary from direct food products, such as meat, milk, eggs and blood, to such products as dung, wool, hides and draught power. They can also play an important role as cash reserves in low-income mixed farming systems. It has been calculated that some $70 \%$ of the world's rural poor depend on livestock as a component of their livelihoods (Drucker et al., 2001).

The importance of conservation of livestock genetic resources does not necessarily relate only to their potential future use under changed circumstances. The preservation of diversity, including within breed diversity, serves to maintain stability in production systems. Diverse populations show greater ability to survive, produce and reproduce under conditions of fluctuating feed resources and water supply; extremes of temperature, humidity and other climatic factors; and low levels of economic evolution, and their economies can be expected to become sufficiently developed to support conservation based on cultural heritage and other such drivers at some point in the future (Blench, 1999; FAO, 2013b).

\section{CONSEQUENCES OF LACK OF CONSERVATION OF LIVESTOCK GENETIC RESOURCES}

Despite their enormous potential contribution to sustainable development and to reducing hunger and poverty, animal genetic resources for food and agriculture are underutilized and under conserved. Genetic erosion of domestic animal diversity has placed $30 \%$ of the world's breeds of livestock at risk of extinction, often as a result of government policy or programs (Hammond, 1996). The major consequence of lack of conservation of livestock genetic resources amongst others is loss of genetic diversity and variability. Loss of genetic diversity among animal populations occurs due to genetic introgression, crossbreeding, inbreeding, climate change and its related factors. Scientists predict climate change scenarios that will have dramatic effects on livestock production:

- Heat stress caused by rising temperatures will impair reproduction.

- Water, feed and fodder availability will be affected by climate change as well as by increased demand for fuel crops, which will reduce the amount of land and water available for feed crops.

- Vectors that carry animal diseases will be able to expand their ranges to higher elevations and latitudes as temperatures rise, threatening many traditional breeds and leading to further genetic erosion.

\section{CONCLUSION AND RECOMMENDATIONS}

Adequate characterization of Animal genetic resources is a prerequisite for successful management programs and 
for informed decision-making in national livestock development. The seriousness of Animal genetic diversity erosion represents a major threat to agro-biodiversity, agricultural sustainability and the livelihoods of many resource-poor farming families. Animal genetic have economic values (use and non-use values) which are not captured in the market place. The resulting disparity between the private and social costs tends to favor activities that promote the erosion of such resources. Economic valuation of animal genetic is thus important from a policy perspective because it can play a key role in translating such social values into efficient incentives and institutional arrangements for farmers: genetic resource managers and breeders. In order to do so, it is also necessary to identify the winners and losers in policy programs.

\section{CONFLICT OF INTEREST}

The authors declare that they have no conflict of interest.

\section{REFERENCES}

Abdussamad, A. M., Holtz, W., Gauly, M. M. S. Suleiman, M. S., \& Bello, M. B. (2011). Reproduction and breeding in dromedary camels: insights from pastoralists in some selected villages of the Nigeria-Niger corridor. Livestock Research for Rural Development, 23(8).

Adekoya, K. O., Oboh, B. O., Adefenwa, M. A., \& Ogunkanmi, L. A. (2013). Morphological Characterization of Five Nigerian Indigenous Chicken Types. Journal of Scientific and Research Development, 14, 55-66.

Akinola, O. S. (2015). Pig Production. A lecture note on Animal Production Health (302).

Alemayehu, K. (2013). Threats, attempts and opportunities of conserving indigenous animal genetic resources in Ethiopia. African Journal of Agricultural Research, 8(23), 2806-2813.

Assan, N. (2014). Micro-Livestock Farming and Food Security in Sub Saharan Africa. Journal of Animal Production Advances, 2(3), 2806-2813.

Bernard, F. (2015). Role, distribution and perspective of camel breeding in the third millennium economies. Emirates Journal of Food and Agriculture, 27 (4), 318-327.

Blench, R. (1999). Traditional Livestock Breeds: Geographical Distribution and Dynamics in Relation to the Ecology of West Africa. Overseas Development Institute Portland House Stag Place London, SW1E 5DP.

De Vicente, M. C., Guzmán, F. A., Engels, J., \& RamanathaRao, V. (2005). Genetic characterization and its use in decision making for the conservation of crop germplasm. In: J. Ruane and A. Sonnino (ed.) The Role of Biotechnology in Exploring and Protecting Agricultural Genetic Resources. Food and Agriculture Organization of the United Nations, Rome. Pp.121-128.

Drucker, A. G., Gomez, V., \& Anderson, S. (2001). The economic valuation of farm animal genetic resources: a survey of available methods. Ecological Economics, 36(2001), 1-18.

ELBARN ( 2009). ELBARN guidelines. Konstanz, Germany,
European Livestock Breeds Ark and Rescue Net.

FAO (1984). Animal genetic resource conservation by management, databanks and training. Animal Production and Health Paper No. 44/1. Rome.

FAO (1999). Food and Agriculture Organization of the United Nations. The Global stratergy for the Management of Farm animal Genetic Resources. Executive briefing, Rome, Italy.

FAO (2001). Food and Agriculture Organization of the United Nations. World watch list for domestic animal diversity. 3rd Edition. FAO, Rome, Italy.

FAO (2007). The global plan of action for animal genetic resources and the Interlaken declaration on animal genetic resources. International Conference on Animal Genetic Resources for Food and Agriculture. Interlaken, Switzerland, 3-7 September 2007. p.33

FAO. (2013a). Animal Genetic Resources: A safety net for the future. Commission on Genetic Resources for Food and Agriculture.

FAO. (2013b). In vivo conservation of animal genetic resources.FAO Animal Production and Health Guidelines. No. 14. Rome.

Gatenby, R. M. (1995). Sheep, Macmillan Education LTD and CTA, Wageninge, The Netherlands, Pp. 1-149.

Hagmann, J. (2003) Legal and Regulatory Framework for Farm Animal Genetic Resources. Workshop Documentation, Mozambique.

Hall, S. J. G. (1992). Conservation of livestock breeds. CNRS Centre d'EtudesBiologiques de ChizéF 79360 Villiers en Bois, France 1

Hammond, K. (2002). Management of farm animal genetic resources.FAO, Animal Genetic Resources, Animal Production and Health Division, VialedelleTerme di Caracalla-00100, Rome, Italy.

Hammond, K. (1996). The status of global farm animal genetic resources. Paper presented at the Symposium on the Economics of Valuation and Conservation of Genetic Resources for Agriculture, Centre for International Studies on Economic Growth, Tor Vergata University, Rome.

Ibitoye, B. A., \& Hassan, W. A. (2016). Camels and donkeys as pack and transport animals in semi-arid Northern Nigeria: herd composition, management and utilization. FAO Corporate Document Repository.

Ibitoye, W. A., \& Bode, A. (2003). Camels and donkeys as pack and transport animals in semi-arid Northern Nigeria: herd composition, management and utilization. Federal University of Agriculture, Abeokuta, Ogun State, Nigeria.

Iregbu, G. U., Kubkomawa, I. H., Okoli, C. G., Ogundu, E. C., Uchegbu, M. C. \& Okoli, I. C. (2014). Environmental Concerns of Pig Waste Production and its Potentials as Biofuel Source. Journal of Animal and Veterinary Sciences, 1(3), 17-24.

Mailafia, S., Onakpa, M. M., \& Owoleke, O. E. (2010). Problems and Prospects of Rabbit Production In Nigeria - A Review. Bayero Journal of Pure and Applied Sciences, 3(2), 20-25.

Mammeri, A., Kayoueche, F. Z., \& Benmakhlouf, A. (2014). Peri-Urban Breeding Practice of One-Humped Camel (CamelusDromedarius) in the Governorate OfBiskra (Algeria); A New Option. Journal of Anim. Prod. Adv., 4(5), 403-415.

NAAS (2001). Conservation and Management of Genetic Resources of Livestock. National Academy of Agricultural Sciences, India.

Oluwatusin, F. (2014). Determinants of Rabbit Keeping in the Tropics: Evidence from Nigeria. Journal of Economics and Sustainable Development, 5(6), 57-62. 
Rege, J. E. O. (1992). Background to ILCA's animal genetic resources characterization project, objectives and agenda for the research planning workshop. In J.E.O. Rege and M.E. Lipner, eds. Animal genetic resources:their characterization, conservation and utilization. Research planning workshop, International Livestock Centre for Africa, Addis Ababa, Ethiopia, 19-21 February, 1992, pp. 55-59.

Rege, J. E. O., \& Lipner, M. E. (1992). African Animal Genetic Resources: Their Characterization, Conservation and Utilization. Proceedings of the Research Planning Workshop held at ILCA, Addis Ababa, Ethiopia 19-21 February 1992.

Renée, B., \& Aloyzas, J. (2003). Farm animal reproduction: Conserving local genetic resources. Proceedings from a minisymposium at Lithuanian Veterinary Academy, Kaunas, Lithuania September 13-15, 2003

RIM, (1992). Nigerian National Livestock Resource Survey. (IV vols). Report by Resource Inventory and Management Limited (RIM) to FDL and PCS, Abuja, Nigeria.

Rotimi, E. A., Egahi, J.O., \& Adeoye, A. A. (2013). Pre- and post-weaning growth performance of Uda and Balami in the semi-arid region of Nigeria. Scholarly Journal of Agricultural Science, 3(2), 58-61.
Tizhe, M. A., Kubkomawa, H. I., Butswat, I. R. S., Addass, P. A., \& Kwaji, D. T. (2015). Characterization of reproductive organs of female goats in Guinea Savannah Zone of North-Eastern Nigeria. Sky Journal of Agricultural Research, 4(3), 047 - 059.

Wilson, R. T., \& Light, D. (1986). Livestock production in central Mali: Economic characters and productivity indices for traditionally managed goats and sheep. Journal of Animal Science 62, 567-575

Wollny, B. A. C. (2001). The Need to Conserve Farm Animal Genetic Resources Through Community-Based Management in Africa: Should policy makers be concerned? Social Science Research Network Electronic Paper Collection: University of Goettingen Institute of Animal Breeding and Genetics, Goettingen, Germany http://papers.ssrn.com/sol3/ papers.cfm?abstract_id=296948. Assessed 20th February, 2016.

Yunusa, A. J., Salako, A. E., \& Oladejo, O. A. (2013). Morphometric characterization of Nigerian indigenous sheep using multifactorial discriminant analysis. International Journal of Biodiversity and Conservation. 5(10), 661-665. 